\title{
USE OF SEROLOGY, SDS-PAGE, AND RAPD ANALYSIS TO EVALUATE RESISTANCE OF FLAX TO POWDERY MILDEW
}

\author{
HUSSEIN, E.M. ${ }^{1}$, M.T.M. MANSOUR ${ }^{1}$, MAGGIE E.M. HASSAN ${ }^{1}$, EMAN A. EL- \\ KADY $^{2}$ AND ${ }^{*}$ K. K. KASEM $*^{1}$
}

1. Plant Pathology Research Institute, ARC, Giza, Egypt.

2. Field Crops Research Institute, ARC, Giza, Egypt.

(Manuscript received 3 November 2010)

\begin{abstract}
Eight flax cultivar were evaluated for powdery mildew resistance under field conditions, C.I. 2008, Cortland, Linore and the local cultivars Giza 8 , Giza 7 were highly susceptible. Disease severities on these cultivars were 100.00, 99.48 and $95.26,93.46$ and $87.26 \%$ respectively. On the other hand, cultivars Williston brown, Wilden and Dokota were highly resistant, with disease severities on these cultivars were $27.58,25.11$ and $19.67 \%$, respectively. SDSPAGE, RAPD analysis by using four primers and double diffusion test (DDT) were used to differentiate between resistance and susceptible genotypes. RAPD analysis by using primer no. 6 and DDT were able, at least partially, to differentiate between resistant and susceptible genotypes, while SDS-PAGE was unable to differentiate between cultivars of the two groups.
\end{abstract}

\section{INTRODUCTION}

Powdery mildew (PM) of flax (Linum usitatissimum L.) is caused by the obligate parasite Oidium lini Škoric. This fungus is found on flax in Egypt only in its imperfect (conidial) stage. The pathogen infects all the aboveground flax organs including stems, leaves, flowers and capsules. PM occurs annually in all flax-production areas in Egypt (Mansour, 1998).Currently, all commercially grown flax cultivars are susceptible to the disease, although field observations indicated that some experimental lines were more susceptible than others(Mansour, 1998). Fungicides are currently the only commercially available management practice for controlling the disease and minimizing associated losses in seed and straw yield (Mansour et al., 1998). Use of cultivars with PM resistance can resolve the problems associated with the use of fungicides in combaling the disease. Currently, field evaluation is the only reliable method to distinguish flax genotypes with PM resistance. However, the precision of field evaluation of genetic resistance is adversely affected by environmental variation and variable levels of natural inoculum. In addition, field evaluation is costly and timeconsuming.

Present address:Agricultural Research Center in Hamh,General Commission for Scientific Agricultural Research,Syria 
Therefore, other reliable methods, either alternative or complementary to field evaluation, is required for the identification of flax genotypes with PM resistance.

One of the theories that has been proposed to explain the primary factor in the plant-parasite interaction, which would lead to susceptibility or resistance of the plant is the degree of antigenic parity between the plant and the pathogen. According to this concept, the greater the antigenic parity between the plant and the pathogen, the greater will be the susceptibility of the plant to the pathogen. It seems that the presence of common antigens may be an important factor that prevents triggering the plant defense mechanism, thus allowing the pathogen to parasitize the plant (Charudattan and DeVay, 1972).

Charudattan and Devay (1972) postulated that the common antigen may be involved in the establishment and survival of Fusarium isolates in host tissue. Similar conclusions was reported by (Shadi et al., 2000) with respect to the fusarium wilt in cotton.

Hussein et al (1997) reached the same conclusion with respect to the host parasite relationship of Rhizoctonia solani and some host and non host plants.

Amino acid sequence of polypeptides (components of proteins) are dependent on nucleotide sequences of their coding genes; therefore, an analysis of protein variation among flax genotypes by electrophoresis, approximates an analysis of their genetic variation (Markert and Faulhaber, 1965).

Some attempts were made to differentiate among flax genotypes by using protein electrophoresis. For example, Lapina and Rullin (1985) electrophoretically analyzed the protein fractions in the stems of four flax varieties at different phases of growth. They reported that some fractions were present in each variety throughout the growth cycle, and that greater number of fractions were found at the phase of rapid growth. They identfied each variety by a characteristic protein fraction (or a group of fractions) at each stage of growth. In a study of protein banding patterns of eight flax varieties differing in resistance to lodging and fungal diseases, Lapina and Rullin (1985)reported that these patterns contained 15-22 bands, with the fewest being found in the petterns of the varieties susceptible or only moderately resistant to lodging and fungi. There were cultivar- specific bands by which the cultivars could be identified. Lapina and Kel'ner (1990) examined the electrophoretic characteristics of the seed protein of four flax cultivars differing in yield, resistance to lodging, and resistance to fungal diseases. They found that there were differences between protein banding patterns of the studied characters, and that patterns had bands in common and cultivar-specific bands. There were 45 bands common to all the cultivars and 2 to 6 associated with the genotype of the particular seeds. They also reported that the 
cultivar, which had the widest range of economiclly useful traits had the highest number of bands in its pattern (71 bands).

Molecular genetic markers have developed into powerful tools to analyze genetic relationships and genetic diversity. Restriction fragment length polymorphisms (RFLPs) can be used, but they are costly and time-consuming. Random amplified polymorphic DNA (RAPD) is a useful technique to evaluate taxonomic identity and kinship (Hadrys et al., 1992). RAPDs were shown to provide a level of resolution equivalent to RFLPs for determining genetic relationships among Brassica oleracea $\mathrm{L}$. genotypes (Dos Santos et al., 1994) and among B. napus L. breeding lines (Hallden et al., 1994). The technical simplicity and speed of RAPD methodology is a principal advantage (Gepts, 1993). Estimates of similarity based on RAPDs have been developed for Gossypium (Pendse et al., 2001).

Resistance of Flax to powdery mildew was quantified by stepwise regression analysis of data generated by double diffussion ,SDS-PAGE, and RAPD in previous papers (Hussein et al., 2003 ,Aly et al., 2004and 2006).

The present study was initiated to determine whether powdery mildew resistant flax cultivars can be distinguished by using double diffusion (DD) antigen and antibodies reactions, SDS-PAGE, or RAPD analysis of DNA. Cluster analysis was used to analyse the generated data.

\section{MATERIALS AND METHODS}

\section{Evaluation of flax genotypes for PM resistance}

Experiments were conducted in 2001/2002 and 2002/2003 growing seasons. Experiment consisted of a randomized complete block design of 5 replicates (blocks). Plots were $2 \times 3 \mathrm{~m}\left(6 \mathrm{~m}^{2}\right)$ and consisted of ten rows spaced $20 \mathrm{~cm}$ apart. Seeds of each genotype were sown by hand at a rate of $70 \mathrm{~g} / \mathrm{plot}$. Planting dates were in the first week of December. Disease severity was rated visually in the last week of April (Nutter et al., 1991)

\section{Extraction of proteins from flax seeds}

Protein extract was prepared from healthy seeds of flax cultivars Giza 7, Giza 8, C.I. 2008, Linore, Cortland, Williston Brown, Wilden and Dakota according to Hussein (1992). The protein content in the resulting supernatant was adjusted to a 3 to 4 $\mathrm{mg} / \mathrm{ml}$ using Bradford spectrophotometric method using bovine serum albumin as a standard protein(Hussein, 1992). 


\section{Extration of protein from healthy and powdery mildew- infected-plants}

Healthy and infected fresh whole plants of flax Giza 7 was ground in liquid nitrogen to a fine powder. The powder was suspended in a solution (1-3 $\mathrm{ml} / \mathrm{g}$ plants) consisting of $12.5 \%$ glucose and $1 \mathrm{~g}$ ascorbic acid dissolved in $100 \mathrm{ml}$ phosphate buffer ( $\mathrm{pH}$ 8.3) and contrifuged at $19000 \mathrm{rpm}$ for 30 minutes at $10^{\circ} \mathrm{C}$ (Hussein, 1992) and the protein content was adjusted as previously mentioned.

\section{Immunization and preparation of antisera}

New Zealand rabbits, 3-4 kg weight, were immunized by flax antigens (infected whole plants of Giza 8). The first injection was given intra-cutaneously in the back between ears. This injection consisted of $0.5 \mathrm{mg}$ protein suspended in $1 \mathrm{ml}$ phosphate buffer and mixed with $1 \mathrm{ml}$ Freund's incomplete adjuvant (Difco). After one week, each animal received $4 \mathrm{mg}$ protein administered intramuscularly in the thigh every third day in a series of twelve injections. One week after the last injection, the animal was bled from the marginal ear vein. Collected blood was kept at room temperature for 1 to $2 \mathrm{hr}$. Clots were then gently lossened and stored over night at $4^{\circ} \mathrm{C}$. Antisera were then decanted and clarified by centrifugation at $10000 \mathrm{rpm}$ for 30 minutes, subdivided into small vials after being subjected to receprocal adsorbition by healthy plant antigens portions in serum. and stored frozen until the time of use. Antiserum of Oidium lini was obtained by the elimination of Giza 8 antibodies from the antiserum of the infected whole plant through the adsorption of plant antibodies (Hussein, 1992) .

\section{Double diffusion technique}

The technique was carried out according to Hussein (1992). Molten 2\% ionagar (Sigma), in saline buffer and supplemented with merthiolate $(1: 10.000$,$) , was poured$ into $9 \mathrm{~cm}$ diameter petri dishes to obtain a layer of agar 1-2 $\mathrm{mm}$. The diameter of the central and the peripheral wells was 10 and $5 \mathrm{~mm}$, respectively. The distance between the central well and the peripheral ones was $15 \mathrm{~mm}$. The central well was filled with infected whole plants antiserum or the pathogen ( $O$. lini) antiserum, and the peripheral wells with antigens of healthy flax (Giza 8, CI 2008, Linore, Cortland, Williston Brown, Wilden, Giza 7 and Dakota). Plates were kept under humid conditions at room temperature $\left(18-24^{\circ} \mathrm{C}\right)$ in the dark for $48-72$ hours. Agar was stained with Commassie Brilliant Blue R-250. The developing precipitin lines were examined and recorded by hand drawing.

\section{Electrophoresis of dissociated protein (SDS-PAGE)}

For electrophoresis of dissociated proteins, each supernatant was mixed with an equal volume of a solution consisting of (by volume) $64 \%$ buffer $(0.15 \mathrm{M}$ Tris- $\mathrm{HCl}, \mathrm{pH}$ 
6.8); $20 \%$ glycerol; $6 \%$ sodium dodecyl sulfate (SDS); $10 \%$ 2-6-mercaptoethanol; and $0.1 \%$ bromophenol blue, and boiled in a water bath for 3 minutes. Twenty-microliter samples ( $40 \mu \mathrm{g}$ of proteins) were subjected to electrophoresis in $15 \%$ polyacrylamide gel prepared in 0.1\% SDS and stained with Brilliant Blue R-250 ( Hussein ,1992).

\section{DNA isolation and RAPD technique}

DNA was isolated from $50 \mathrm{mg}$ of organism using Qiagen kit for DNA extraction. The extracted DNA was dissolved in $100 \mu$ of the elution buffer. The concentration and purity of the obtained DNA was determined by using "Gen qunta" systemPharmacia Biotec. The purity and ratio of the DNA for all samples was between 90$97 \%$ and between 1.7-1.8 recpectively. Concentration was adjusted at $6 \mathrm{ng}$ for all samples using TE buffer, $\mathrm{pH} 8.0$.

\section{Random amplified polymorphism DNA technique (RAPD)}

Thirty ng from the extracted DNA were used for the amplification reaction. The polymerase chain reaction (PCR) mixture contained PCR beads tablet (Amessham Pharmacia Biotec.), which contain all necessary reagents except the primer and the DNA which was added to the tablet.

The kits of Amessham Pharmacia Biotec kits also included the following primers. Five microliters of the primer (10 mer) were added.. The sequences of the primers tried were:

RAPD Analysis Primer 1:6 d (CGTGCGGGAA)-3

RAPD Analysis Primer 2:6 d (GTTTCGCTCC)-3

RAPD Analysis Primer 5:6 d (AACGCGCAAC)-3

RAPD Analysis Primer 6:6 d (CCCGTCAGCA)-3

The total volume was completed to $25 \mu \mathrm{l}$ with sterile distilled water. The amplification protocol was carried out as follows using PCR unit II biometra.

a) Denaturation at $95^{\circ} \mathrm{C}$ for 5 minutes.

b) 45 cycles each consists of the following steps:

1. Denaturation at $95^{\circ} \mathrm{C}$ for $1 \mathrm{~min}$..

2. Annealing at $36^{\circ} \mathrm{C}$ for $1 \mathrm{~min}$..

3. Extension at $72^{\circ} \mathrm{C}$ for $2 \mathrm{~min}$.

c) Final extension at $72^{\circ} \mathrm{C}$ for $5 \mathrm{~min}$.

d) Hold at $4^{\circ} \mathrm{C}$.

Seven $\mu \mathrm{l}$ of $6 \mathrm{X}$ tracking buffer (manufactured by Qiagen kit) were added to 25 $\mu \mathrm{l}$ of the amplification product. 


\section{Amplification product analysis}

The amplified DNA for all samples were electrophoresed(15 $\mu \mathrm{l})$ using electrophoresis unit (WIDE mini-sub-cell GT Bio-RAD) on 1\% agarose containing ethidium bromide $(0.5 \mu \mathrm{g} / \mathrm{ml})$ at 75 constant volt, and determined with UV transilluminator.

\section{Gel Analysis}

All kinds of gels (protein, and DNA) were scanned for band $R_{f}$ using gel documentation system (AAB Advanced American Biotechnology 1166). The different M.W. of band were determined against PCR marker promega G 317A by unweighted pair-group method based on arithmetic mean (UPGMA).

\section{Statistical analysis of the data}

\section{a. Field trial}

The experimental design of the field trials was a complete randomized with five replications. Analysis of variance (ANOVA) of the data was performed with the MSTATC Statistical Package (A Microcomputer Program for the Design, Management and Analysis of Agronomic Research Experiments, Michigan State Univ., USA). Least significant differences (LSD) test was used to compare cultivar means.

\section{b. Serology test}

Simple matching coefficient (SSM) was determined for each pair of cultivars as described by Sokal and Michener (1958) by the formula SSM $=(\mathrm{m} / \mathrm{m}+\mathrm{u}) \times 100$, where $\mathrm{m}=$ number of pairs of precipitin lines found in common between the two fractions, and $u=$ the total number of precipitin lines unique to each host. The resulting similarity matrix was subjected to cluster analysis ( Hussein ,1992) by the average linked technique (unweighted pair-group method).

\section{c. Electrophoretic proteins}

Electrophoretic protein patterns obtained by SDS-PAGE were clustered (Joseph et al., 1992) by the average linked technique (unweighted pair-group method). The results were expressed as phenograms. Cluster analysis was performed by a computerized program.

\section{d. PCR technique}

A gel documentation system was used (AAB Advanced American Biotechnology). The similarity levels were determined by the unweighted pair-group method based on arithmetic (UPGMA) and Pearson's correlation coefficient. 


\section{RESULTS AND DISCUSSION}

\section{Evaluation of falx genotypes for PM resistance}

Evaluation of flax cultivars reaction to PM (Table I) revealed that the tested cultivars could be classified into two distinct groups. Susceptible and less suscetible cultivars (Giza 8, Cortland, Linore, C.I. 2008 and Gzia 7). Disease severities on these cultivars were 93.46, 99.48,95.26, 100.00, and $87.26 \%$, respectively. and resistant cultivars (Dakota, Wilden and Williston Brown).Showing disease severities of 19.67, 25.11 and 27.58 , respectively.

Table 1. Reaction of eight flax cultivars to powdery mildew under field conditions in 2001/200 2and 2002/2003 growing seasons.

\begin{tabular}{lc}
\hline Cultivar & Disease severity ${ }^{\text {a } \%}$ \\
\hline Dakota & $19.67^{\mathrm{b}}$ \\
Wilden & 25.11 \\
Williston Brown & 27.58 \\
Cortland & 99.48 \\
Linore & 95.26 \\
C.I. 2008 & 100.00 \\
Giza 7 & 87.26 \\
Giza 8 & 93.46 \\
\hline
\end{tabular}

$\operatorname{LSD}=8.06(P<0.05)$

$\mathrm{LSD}=11.19(\mathrm{P}<0.01)$

${ }^{a}$ Disease severity was the percentage of infected leaves per plant in a random sample of the plant per plot.

${ }^{b}$ Means of two seasons.

\section{Double diffusion test}

Fig. 1 ( 3 and 4) and Table (2) show the antigenic relationship between 0 . lini and flax cultivars. The number of common antigens ranged from 1 to 3 . There were no common antigens between $\boldsymbol{O}$. lini and cultivars Dakota, and Wilden Williston Brown.

Double diffusion data were used to calculate simple matching coefficient (SSM) shown in Table (3). A phenogram (Fig. 2) on the distances generated from cluster analysis of SSM established among the related. cultivars The smaller the distance (D), the more closely the cultivars were. In this phenogram, the cultivars were placed in two unrelated subclusters. The first one $(D=21.25)$ included the resistant cultivars Wilden and Williston Brown, while the second one $(D=15)$ included all the other cultivars, which were the moderately susceptible cultivar Giza 7, the susceptible 
cultivars Giza 8, Cortland, Linore and C.I. 2008 and the resistant cultivar Dakota. The lowest $D$ in the subcluster was found between the two local cultivars Giza 7 and Giza 8 indicating very high degree of similarity.

Table 2. Number of distribution protein fractions obtained by double diffusions reaction of Odiium lini antiserum against antigens of eight flax cultivars.

Protein

Antiserum of $O$. lini $x$ antigens of flax cultivars

fraction

\begin{tabular}{|c|c|c|c|c|c|c|c|c|}
\hline No. & $\begin{array}{c}\text { Giza } \\
7\end{array}$ & $\begin{array}{c}\text { Giza } \\
8\end{array}$ & Dakota & Wilden & $\begin{array}{c}\text { Williston } \\
\text { Brown }\end{array}$ & ortland & Linore & CI 2008 \\
\hline 1 & - & - & - & - & - & - & - & + \\
\hline 2 & - & - & - & - & - & + & + & + \\
\hline 3 & + & + & - & - & - & + & + & + \\
\hline
\end{tabular}

$(+)=$ Protein fraction was present.

$(-)=$ Protein fraction was absent.

Table 3. Matrix containing simple matching coefficients (SSM) ${ }^{a}$ established among eight flax cultivars

Cultivar

Cultivars

\begin{tabular}{|c|c|c|c|c|c|c|c|c|}
\hline \multirow{2}{*}{$\overline{\text { Giza } 7}$} & \multirow{2}{*}{$\begin{array}{c}\begin{array}{c}\text { Giza } \\
7\end{array} \\
100\end{array}$} & \multirow{2}{*}{$\begin{array}{c}\text { Giza } \\
8 \\
100\end{array}$} & \multirow{2}{*}{$\begin{array}{c}\text { Dakota } \\
50\end{array}$} & \multirow{2}{*}{$\begin{array}{c}\text { Wilden } \\
0\end{array}$} & \multicolumn{2}{|c|}{$\begin{array}{l}\text { Williston Cortland } \\
\text { Brown }\end{array}$} & \multirow{2}{*}{$\begin{array}{c}\text { Linore } \\
50\end{array}$} & \multirow{2}{*}{ CI 2008} \\
\hline & & & & & 0 & 50 & & \\
\hline Giza 8 & 100 & 100 & 0 & 0 & 0 & 50 & 50 & 33 \\
\hline Dakota & 0 & 0 & 100 & 0 & 0 & 0.0 & 0.0 & 0.0 \\
\hline Wilden & 0 & 0 & 0 & 100 & 0 & 0 & 0 & 0 \\
\hline \multicolumn{2}{|c|}{ Williston Brown0.0 } & 0 & 0 & 0 & 100 & 0.0 & 0.0 & 0 \\
\hline Cortland & 50 & 50 & 50 & 0 & 0 & 100 & 100 & 66 \\
\hline Linore & 50 & 50 & 50 & 0 & 0 & 100 & 100 & 66 \\
\hline C.I. 2008 & 33 & 33 & 33 & 0 & 0 & 66 & 66 & 100 \\
\hline
\end{tabular}

a Simple matching coefficient (SSM) was determined for each pair of cultivars as described by Sokal and Michner (1958) by the following formula SSM $=(\mathrm{m} / \mathrm{m}+\mathrm{u}) \mathrm{x}$ 100 , where $\mathrm{m}=$ the number of pairs of preciptin lines found in common between the two cultivars and $u=$ the total number of precipitin lines unique to each host.. 

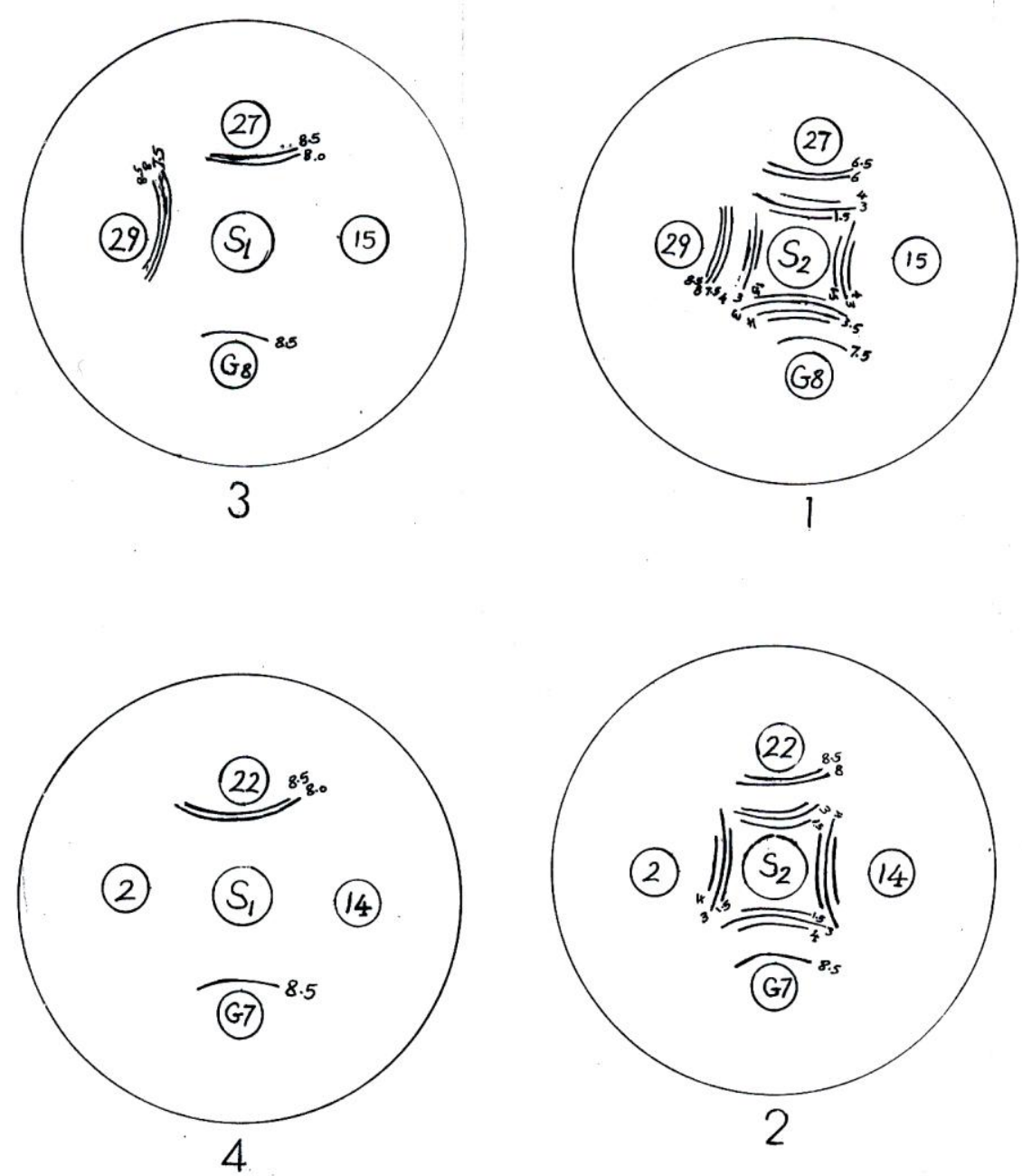

Fig. 1. Diagram showing the double-difussion reaction of the antiserum $\left(\mathrm{S}_{1}\right)$ of Oidium lini $(3,4)$ and the antiserum $\left(S_{2}\right)$ of infected whole plant of Giza $80(1,2)$ against antigens of healthy flax seeds of eight cultivars.Cultivars were: Cortland (22), Linore (27), C.I. 2008 (29), Dakota (2), Wilden (14), Williston Brown (15), Giza 7 and Giza 8 . The band is followed by anumber represents the distance $(\mathrm{mm})$ between the band and the centtal well.

\section{Antiserum of infected whole plants (Giza 8)}

Fig. $1(1,2)$ and Table (4) show the antigenic relationships between antiserum of infected Giza 8 and antigens of the healthy flax cultivars. The number of comon antigens ranged from 3 to 6 . Dakota and Wilden showed the least number of common antigens with the infected Giza 8. A phenogram was constructed (Fig. 3), based on cluster analysis of SSM values shown in Table (5). The phenogram was divided into two distinct unrelated subcluster. The first one $(D=16.25)$ included the susceptible cultivars Cortland, Linore, C.I. 2008 and Giza 8 and the resistant cultivar Williston Brown, while the second one $D=15$ ) included cultivars Dakota and Wilden. 
Table 4. Number and distribution protein fractions obtained by double diffusions reaction of infected hole plant antiserum against antigens of eight flax cultivars.

\begin{tabular}{|c|c|c|c|c|c|c|c|c|}
\hline \multirow{2}{*}{$\begin{array}{l}\text { Protein } \\
\text { fraction } \\
\text { No. }\end{array}$} & \multicolumn{7}{|c|}{ Antiserum of infected Giza $8 x$ antigens of flax cultivars } & \multirow[b]{2}{*}{ CI 2008} \\
\hline & $\begin{array}{c}\text { Giza } \\
7\end{array}$ & $\begin{array}{c}\text { Giza } \\
8\end{array}$ & Dakota & Wilden & $\begin{array}{c}\text { Williston } \\
\text { Brown }\end{array}$ & ortland & Linore & \\
\hline 1 & + & + & + & + & + & + & + & + \\
\hline 2 & + & + & + & + & + & + & + & + \\
\hline 3 & - & + & - & - & - & - & - & - \\
\hline 4 & + & + & + & + & + & + & + & + \\
\hline 5 & - & + & - & - & - & - & - & + \\
\hline 6 & - & - & - & - & + & + & + & + \\
\hline 7 & + & - & - & - & + & + & + & + \\
\hline
\end{tabular}

$(+)=$ Protein fraction was present.

$(-)=$ Protein fraction was absent.

a Disease severity was the percentage of infected leaves per plant in a random sample of plant pe plot.

Distance

Giza 7

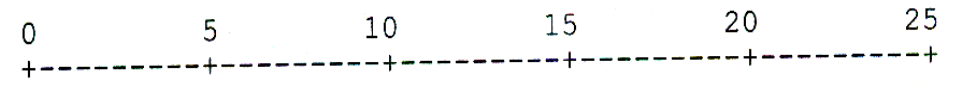

Giza 8

Linore

C.I. 2008

Cortland

Dakota

Wilden

Williston Brown

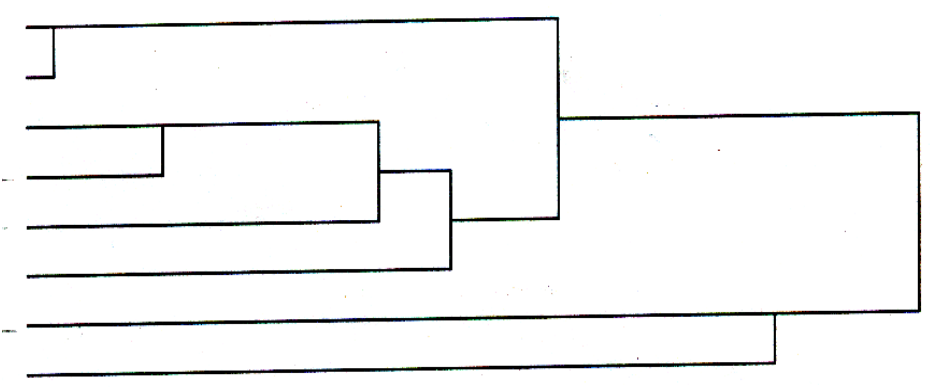

Fig. 2. Phenogram based on average of linkage cluster analysis of serological patterns obtained by double-diffusion technique of antigens of eight flax cultivars reached against antiserum of 0 . lini.

Two methods were used to study the serological relatedness between eight flax cultivars having varying levels of powdery mildew resistance. In the first method, antiserum of $\boldsymbol{O}$. lini was interacted with antigens of healthy whole plants. In the second method, antiserum of the infected flax cultivar Giza 8 was acted against antigens of healthy whole plants of the eight cultivars. Cluster analysis of this method was partially successful because it placed the resistant cultivars Dakota and Wilden in the same culster with the moderately susceptible cultivar Giza 7. The increase in the number of bands in this method could be ascribed to the interaction of Giza 8 antiserum against antigens of the other flax cultivars. 
Table 5. Matrix containing simple matching coefficients (SSM) ${ }^{\mathrm{a}}$ established among eight flax cultivars.

Cultivar

Cultivars

\begin{tabular}{|c|c|c|c|c|c|c|c|c|}
\hline & $\begin{array}{c}\text { Giza } \\
7\end{array}$ & $\begin{array}{c}\text { Giza } \\
8\end{array}$ & Dakota & Wilden & $\begin{array}{c}\text { Williston } \\
\text { Brown }\end{array}$ & Cortland & Linore & CI 2008 \\
\hline Giza 7 & 100 & 50 & 75 & 75 & 80 & 00 & 80 & 66 \\
\hline Giza 8 & 50 & 100 & 75 & 75 & 80 & 80 & 80 & 60 \\
\hline Dakota & 75 & 75 & 100 & 75 & 60 & 60 & 60 & 50 \\
\hline Wilden & 75 & 75 & 100 & 100 & 60 & 60 & 60 & 50 \\
\hline \multicolumn{2}{|c|}{ Williston Brown80 } & 80 & 60 & 60 & 100 & 100 & 100 & 83 \\
\hline Cortland & 80 & 80 & 60 & 60 & 100 & 100 & 100 & 83 \\
\hline Linore & 80 & 80 & 60 & 60 & 100 & 100 & 100 & 83 \\
\hline C.I. 2008 & 66 & 66 & 50 & 50 & 83 & 83 & 83 & 100 \\
\hline
\end{tabular}

a Simple matching coefficient (SSM) was determined for each pair of cultivars as described by Sokal and Michner (1958) by following formula; SSM $=(\mathrm{m} / \mathrm{m}+\mathrm{u}) \mathrm{x}$ 100 , where $\mathrm{m}=$ the number of pairs of preciptin lines found in common between the two cultivars and $\mathrm{u}=$ the total number of precipitin lines unique to each host.

Distance

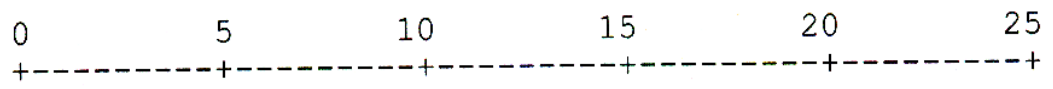

Cortland

Linore

Williston Brown

C.I. 2008

Giza 8

Dakota

Wilden

Giza 7

Fig. 3. Phenogram based on average linkage cluster analysis of serological protein patterns obtained by double-diffusion technique of antigens from eight flax cultivars reacted against antiserum of infected whole plant.

\section{Sodium dodecyl sulfate-polyacrylamide gel electrophoresis (SDS-PAGE)}

The SDS-PAGE analysis of water soluble proteins for flax cultivars Giza 7, Giza 8, Cortland, Linore, C.O. 2008, Dakota, Wilden and Williston Brown is presented in Fig. (4). The phenogram shown in Fig. (5) was established based on cluster analysis of protein banding patterns of the tested cultivars shown in Figure(4). Grouping the cultivars in the phenogram was not related to their susceptibility to powdery mildew. Thus, the susceptible cultivars Cortland and Giza 8 were included in the same 
subcluster with the resistant cultivar Wilden (similarity levels $=96.77 \%$ ). The resistant cultivars Dakota and Williston Brown constituted asingle subcluster remotely related to the resistant cultivar Wilden.

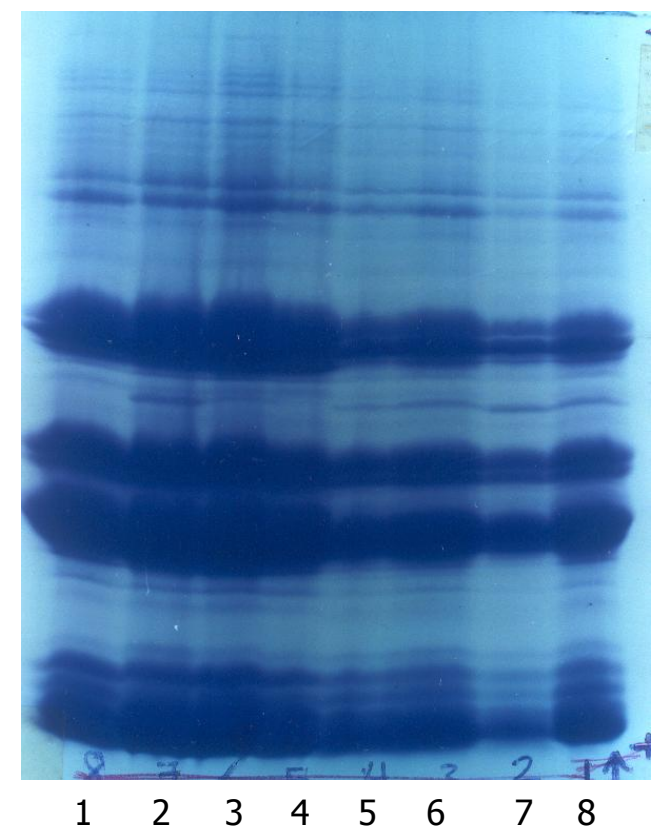

Fig. 4. SDS-PAGE profiles analysis of water soluble seed proteins of eight flax cultiovars. Flax cultivars were Giza 8 (1), Giza 7 (2), C.I. 2008 (3), Linore (4), Wilden (5), Cortland (6), Williston Brown (7), and Dakota (8).

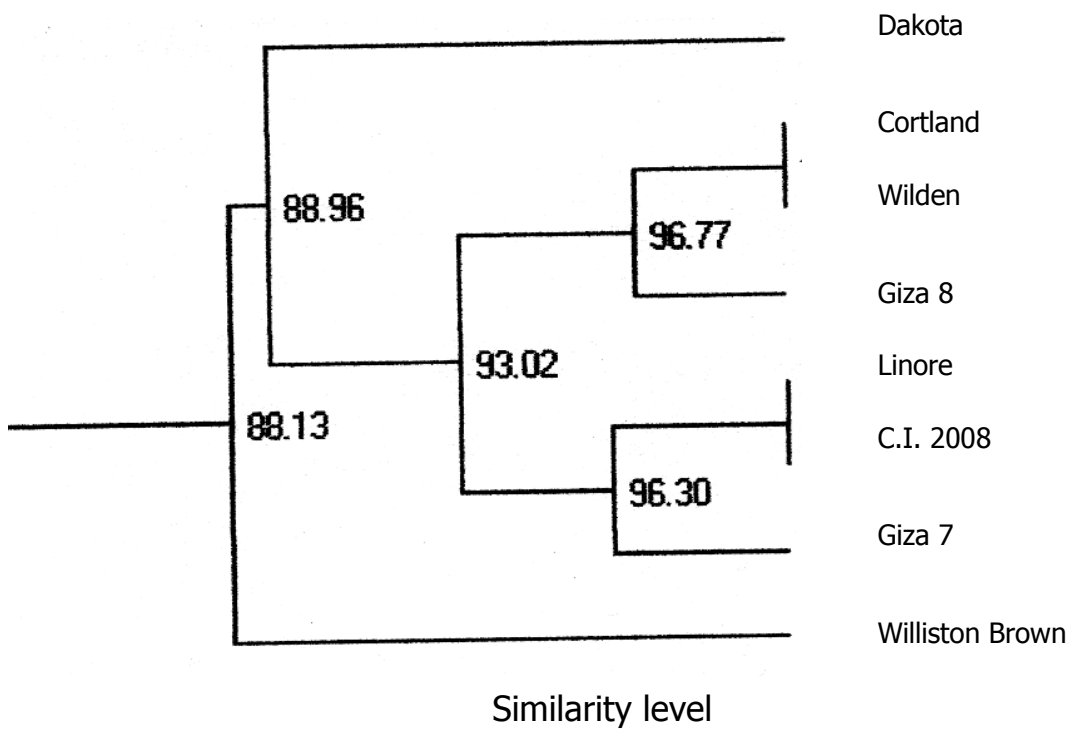

Fig. 5. Phenogram based on average linkage cluster analysis of electrophoretic protein patterns obtained by SDS-polyacrylamide gel for eight flax cultivars.

A problem with proteins as biochemical markers for typing or classification of plants is the vast number, which can be generated. Faced with so much data, only 
sophiusticated analysis can draw meaningful conclusions (Manicom et al., 1990). Therefore, in the present study, we used a computerized gel documentation system for culster analysis as an attempt to distinguish the resistant flax genotype. Cluster analysis of electrophoretic banding patterens of CBB was not sucessful in distinguishing the resistant cultivars because they were placed in separate subclusters.

\section{Random amplified polymorphism DNA (RAPD)}

Figs. (6-13) show the data obtained from RAPD analysis by using primers nos. 1, 2, 5, and 6, respectively. Primer no 1, (Fig. 6 and 7) placed the cultivars in three distinct groups, the first group included Giza 8and Cortland. The second group included Giza 7, Linore, C.I. 2008 and Williston Brown and the third group included Dakota and Wilden. However, grouping the cultivars was not related to their susceptibility to powdery mildew, because cultivar Williston Brown (resistant) was included in the same group with the susceptible cultivars Giza 7, Linore, C.I. 2008. The same results were obtained with primers 2 and 5 (Fig. 8-11). Primer 6,( Fig. 12 and 13) was partilly successful in separating the resistant cultivars Dakota, Wilden and Williston Brown in one subcluster ( $\mathrm{S}=85.71 \%$ ).

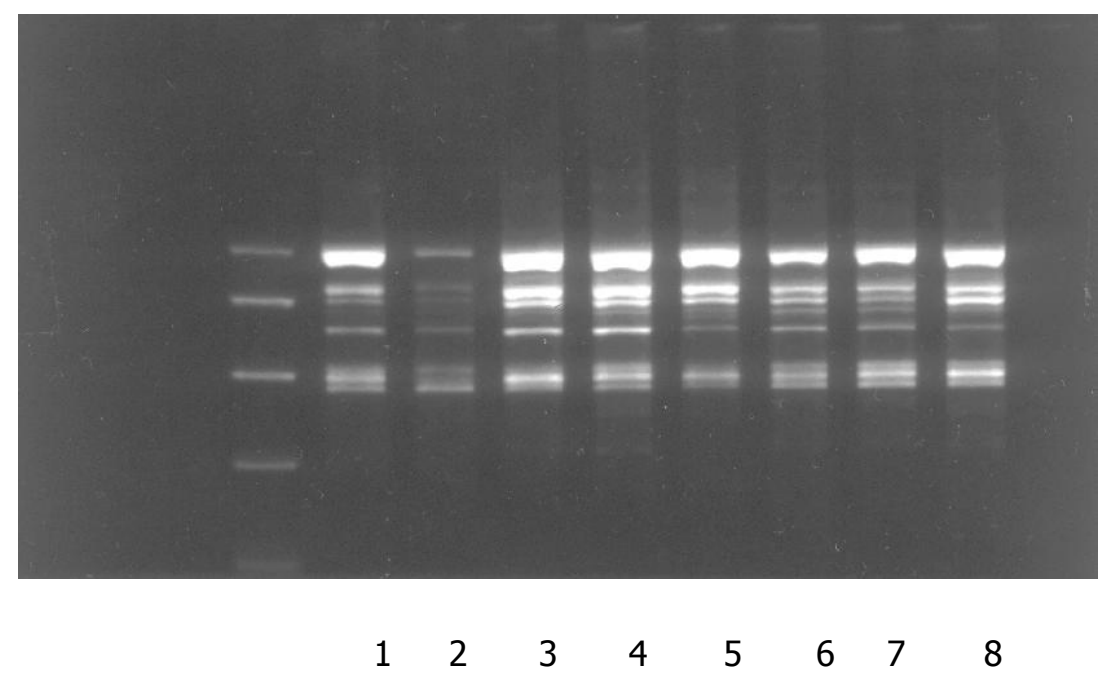

Fig. 6. RAPD banding patterns of flax cultivars by primer No. 1 and electrophoresed on agarose gel.

Cultivars were: Giza 8 (1), Giza (2), Dakota (3), Cortland (4), Wilden (5), Linore (6), C.I. 2008 (7) and Williston Brown (8).. 


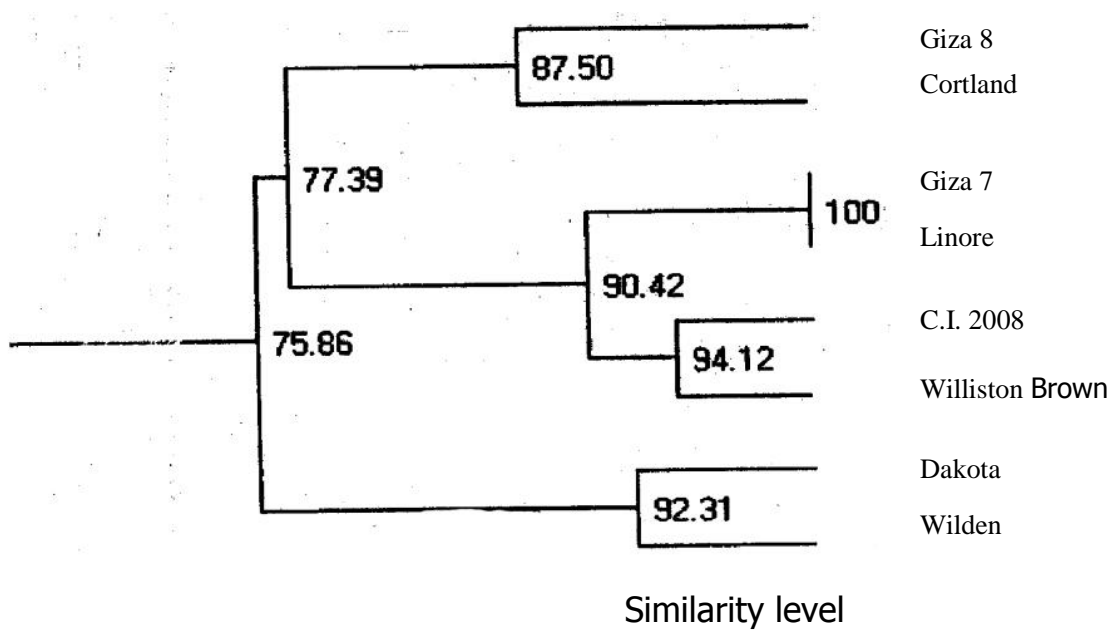

Fig. 7. Phenogram based on cluster analysis of RAPD banding patterns of flax cultivars obtained by primer No. 1 and electrophoresed on agarose gel.

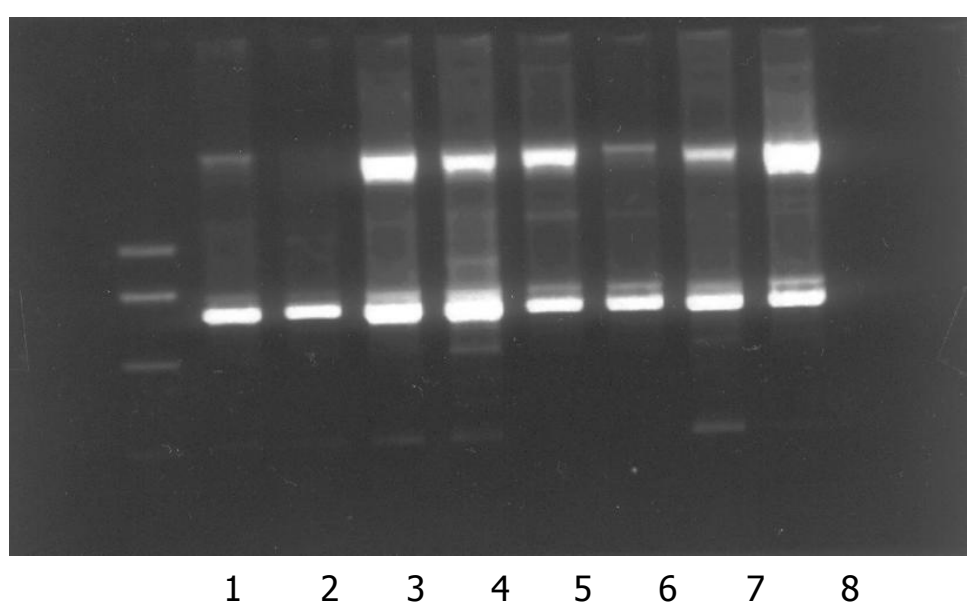

Fig. 8. RAPD banding patterns of flax cultivars by primer No. 2 and electrophoresed on agarose gel.

Cultivars were: Giza 8 (1), Giza (2), Dakota (3), Cortland (4), Wilden (5), Linore (6), C.I. 2008 (7) and Williston Brown (8).

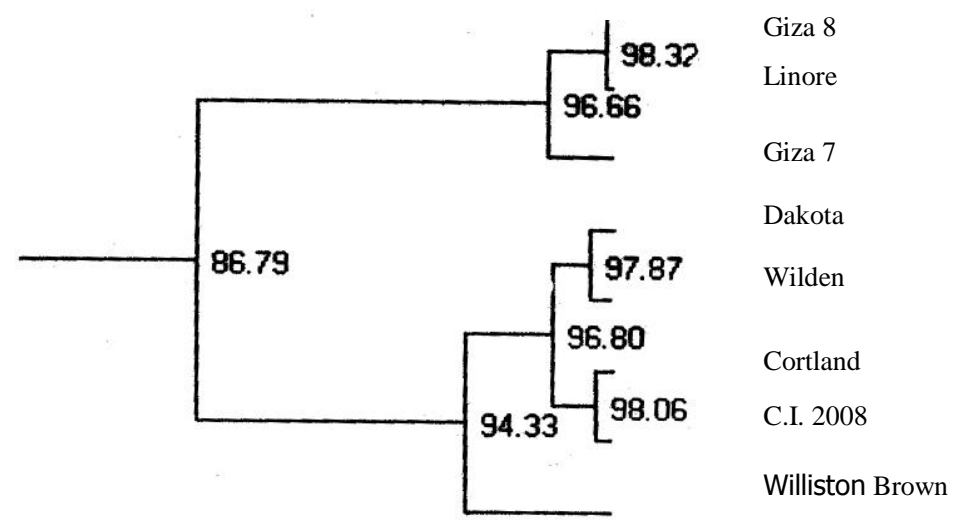

Similarity level

Fig. 9. Phenogram based on cluster analysis of RAPD banding patterns of flax cultivars obtained by primer No. 2 and electrophoresed on agarose gel. 


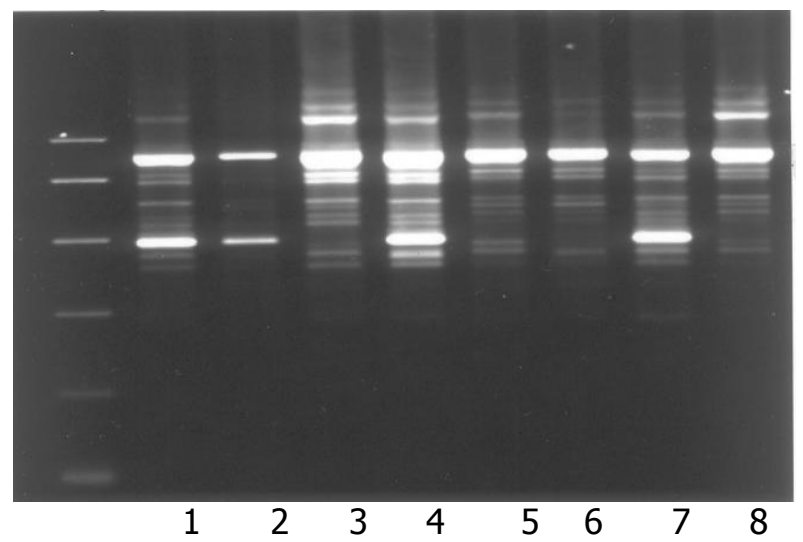

Fig. 10. RAPD banding patterns of flax cultivars by primer No. 5 and electrophoresed on agarose gel.

Cultivars were: Giza 8 (1), Giza (7), Dakota (3), Cortland (4), Wilden (5), Linore (6), C.I. 2008 (7) and Williston Brown (8).

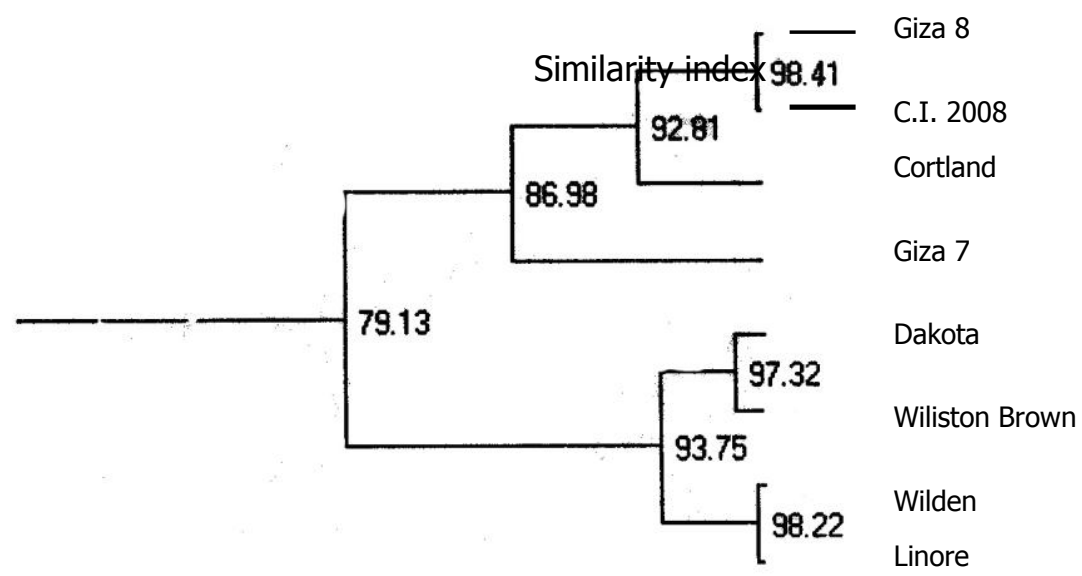

Fig. 11. Phenogram based on cluster analysis of RAPD banding patterns of flax cultivars obtained by primer No. 5 and electrophoresed on agarose gel.

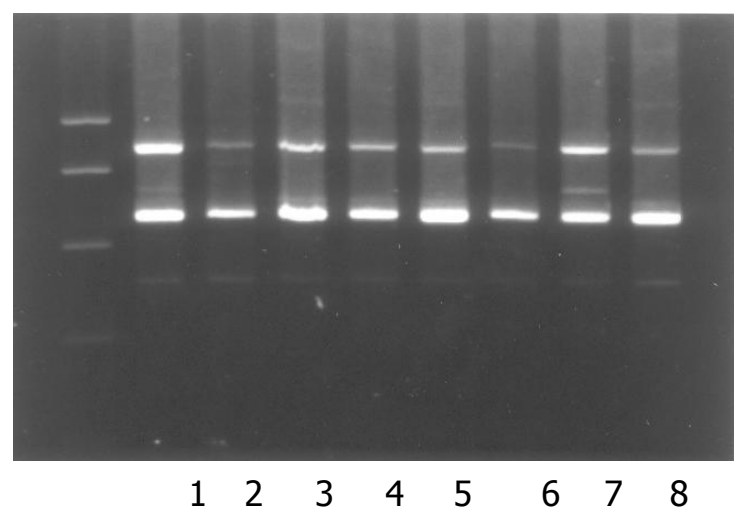

Fig. 12. RAPD banding patterns of flax cultivars by primer No. 6 and electrophoresed on agarose gel.

Cultivars were: Giza 8 (1), Giza 7 (2), Dakota (3), Cortland (4), Wilden (5), Linore (6), C.I. 2008 (7) and Williston Brown (8).. 


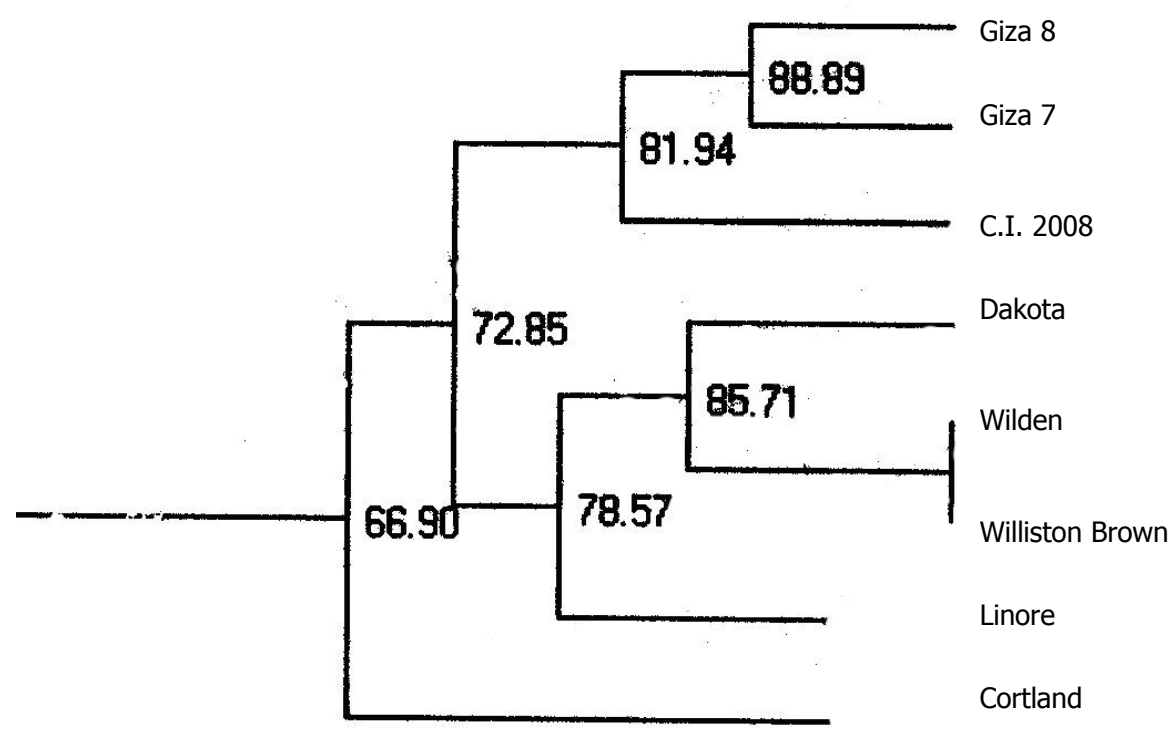

Similarity in Similarity index

Fig. 13. Phenogram based on cluster analysis of RAPD banding patterns of flax cultivars obtained by primer No. 6 and electrophoresed on agarose gel.

RAPD analysis by using primer no. 6 placed the resistant cultivars in the sam subcluster. However, this primerm as well as the other primers were chosen based on cost considerations with the availability of thousands of RAPD primers, many other suitable primers could likely exist.

The results of the present study showed that DD test, RAPD analysis by primer 6 could be used in combination with pathogenicity test, in screening flax genotypes for powdery mildew resistance.

\section{REFERENCES}

1. Aly, A.A., Maggie. E. Mohamed, E.M. Hussien and M.T.M. Mansour. 2004. Quantification of flax resistance to powdery mildew by the random amplified polymeric. DNA (RAPD). Egyptian journal of Agric. Res.. Vol. 82, No. (4): 14991508.

2. Aly, A.A., M.T.M. Mansour and E.M. Hussein. 2006. Use of protein electrophoresis to quantify resistance of flax genotypes to powdery mildew disease. J. Agric. Sci. Mansoura Univ., 31 (1): 213-224.

3. Charudattan, R. and J.E. DeVay. 1972. Common antigen among varieties of Gossypium hirsutum and isolates of Fusarium and Verticillium species. Phytopathology, 62: 230-234.

4. Dos Santos, J.B., J. Nienhuis, P.W. Skorch, J. Tivang, and M.K. Slocum. 1994. Comparison of RAPD and RFLP genetic markers in determining genetic similarity among Brassica oleracea L. genotypes. Theor. Appl. Genet., 87: 909-915. 
5. Gepts, P. 1993. The use of molecular and biochemical markers in crop evolution studies. pp. 51-94. In: Evolutionary Biology (M.K. Hecht, ed.), Vol. 27. Plenum Press, New York.

6. Hadrys, H., M. Balick and B. Schierwater. 1992. Application of random amplified polymorphic DNA (RAPD) in molecular ecology. Mol. Ecol. 1: 55-63.

7. Hallden, C., N.O., Nilsson, I.M. Rading, and T. Sall. 1994. Evaluation of RFLP and RAPD markers in comparison of Brassica napus breeding lines. Theor. Appl. Genet., 88: 123-128.

8. Hussein, E.M. 1992. Biochemical and serological studies for determining susceptibility of cotton cultivars to Fusarium oxysporum f.sp. vasinfectum. (In Russian). Ph.D. Thesis, All-Union Institute of Plant Protection, Leningrad, USSR.

9. Hussein, E.M., A.A. Aly, M.A. Tag El-Din and A.Z. Ashour. 1997. Comparative studies on serological and electrophoretic protein patterns of Rhizoctonia solani and its host and non host plants. J. Agric. Sci. Mansoura Univ. 22: 581-593.

10. Hussein, E.M., A.A Aly and S.M.E. Zayed. 2003. Use of serological interaction to quantity resistance of flax cultivars to powdery mildew disease. J. Agric. Sci. Mansoura Univ., 28 (9), 6655-6663.

11. Lapina, G.P. and E.V. Kel'ner. 1990. Electrophoretic characteristics of seed proteins of flax. Fiziologiya i Biokhimiya Kul'turnykh Rastenii, 22: 87-93.

12. Lapina, G.P. and V.S. Rullin. 1985. Electrophoretic study of the protein fractions in stems of flax at different phases of growth. Fiziologiya i Biokhimiya Kul'turnykh Rastenii, 17: 356-360.

13. Manicom, B.Q., M. Bar-Joseph, and J.M. Kotze. 1990. Molecular methods of potential use in the identification and taxonomy of filamentous fungi, particularly Fusarium oxysporum. Phytophylactica, 22: 223-239.

14. Mansour, M.T.M. 1998. Pathological studies on powdery mildew of flax in A.R.E. Ph.D. Thesis, Zagazig Univ., Moshtohor, 148 p.

15. Markert, C.L. and I. Faulhaber. 1965. Lactate dehydrogenase isozyme patterns of fish. J. Exp. Zool. 159: 319-332.

16. Nutter, F.W., Jr. P.S. Teng and F.M. Sonkes. 1991. Disease assessment terms and concept. Plant Dis. 75: 1187-1188.

17. Pendse, R., S. Malhotra, S.E. Pawar, and T.G. Krishna. 2001. Use of DNA markers for identifying inbreds and hybrid seeds in cotton (Gossypium hirsutum L.). Seed Science and Technology, 29: 503-508.

18. Sokal, R.R. and C.D. Michener. 1958. A statistical method for evaluating systematic relationships. Univ. Kandas Sci. Bull. 38: 1409-1438. 
إستعمال الطرق السيرولوجية والتفريد الكهربى للبروتينات المفككة والتضاعف

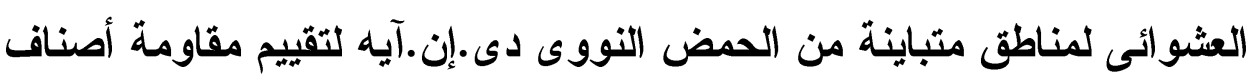

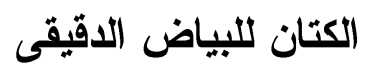

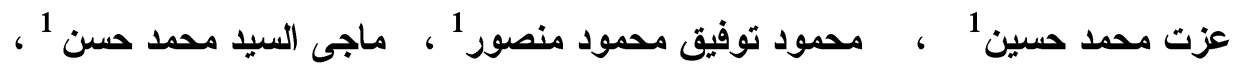

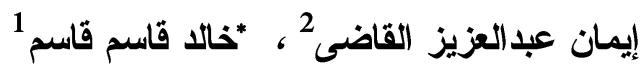

$$
\begin{aligned}
& \text { I . معط بحوث أمراض النباتات - مركز البحوث النزراعية _ الجيزة }
\end{aligned}
$$

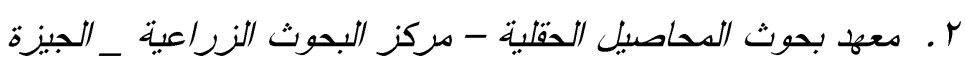

أختبرت ثمانية أصناف من الكتان من حيث المقاومة للإصابة بمرض البياض الدقيقى تحت

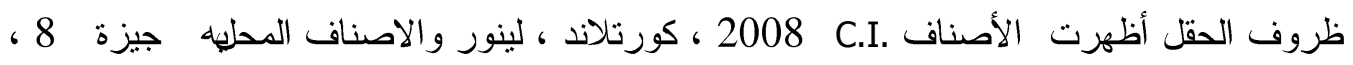

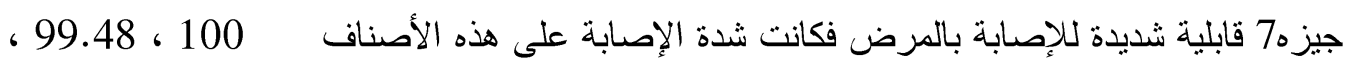

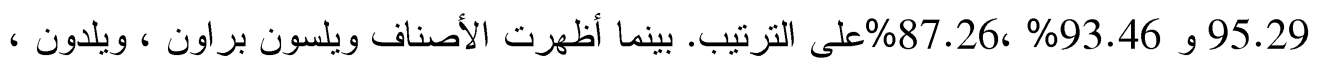

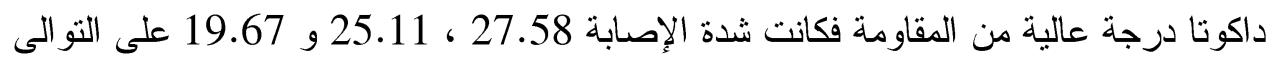

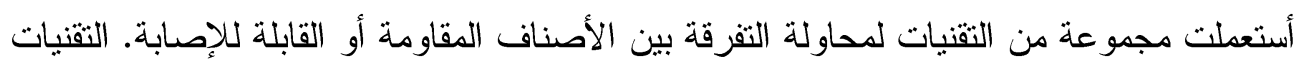

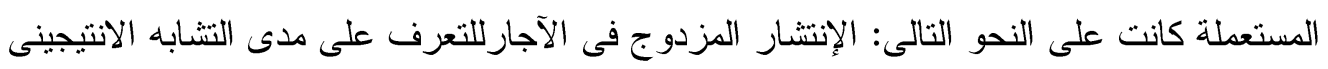

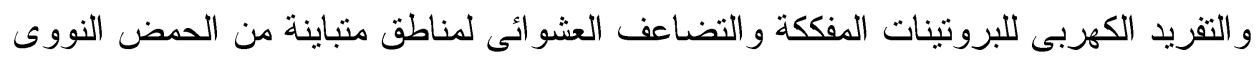

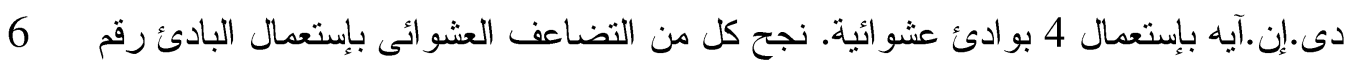

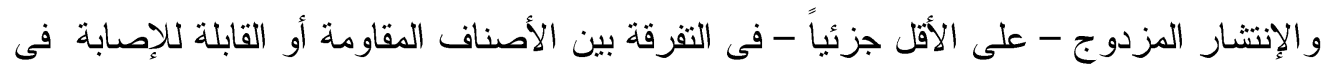
حين فثل التفريد الكهربى للبروتينات الدفككة فى التفرقة بين الدجموعتين. 